\title{
PENGEMBANGAN SISTEM INFORMASI MANAJEMEN PENGOLAHAN NILAI MAHASISWA BERBASIS WEB PADA STMIK AKBA
}

\author{
Markani $^{1}$, Mashud $^{2}$ \\ Sistem Infomasi STMIK AKBA ${ }^{1}$, Komputerisasi Akuntansi STMIK AKBA ${ }^{2}$ \\ Email: markani@akba.ac.id ${ }^{1}$, mashud@akba.ac.id ${ }^{2}$
}

\begin{abstract}
ABSTRAK
Penelitian ini bertujuan untuk menghasilkan perangkat lunak Sistem Informasi Manajemen Pengolahan Nilai Mahasiswa Berbasis Web pada STMIK AKBA yang mampu mengolah nilai mahasiswa secara cepat dan akurat. Jenis penelitian ini adalah Recearch and Depelopment. Metode pengembangan perangkat lunak menggunakan waterfall model. Pengujian perangkat lunak dilakukan melalui pengujian white box dan black box serta melalui pengujian alpha dan beta oleh sejumlah pengguna. Instrument menggunakan faktor kualitas McCall sebagai indikator untuk menentukan tingkat kelayakan perangkat lunak dengan skala pengukuran menggunakan skala Likert. Teknik pengumpulan data pada penelitian ini menggunakan teknik wawancara dan kuisioner. Teknik analisis data menggunakan teknik analisis deskriptif kuantitatif. Hasil penelitian menunjukkan bahwa Sistem Informasi Manajemen Pengolahan Nilai Mahasiswa Berbasis Web ini mampu mengolah nilai mahasiswa secara otomatis dapat menghasilkan nilai mata kuliah yang cepat dan akurat.
\end{abstract}

Kata Kunci : Berbasis Web, Manajemen Pengolahan Nilai Mahasiswa, Sistem Informasi.

\begin{abstract}
The research aims at producing web-based student score processing Management Information System in STMIK AKBA which able to process the students' scores quckly and accurately. The reseach was research and development. The software development method employed waterfall model. The software test was conducted through black and white box testing and through instrument reliability test which was conducted by using alpha Cronbach technique by a number of experts and users. The instrument employed McCall causality factor as indicator to determine the feasibility level of the software with measurement scale, namely Likert scale. The data of the research were collected through interview and questionnnaire technique. The data were analyzed by using quantitative descriptive analiysis technique. The result of the research reveal that the web-based Student Score Processing Management System could process the students' score which automatically could produce the cources's score quickly and accurately.
\end{abstract}

Keyword: Web-Based, Student Score Processing Management, Information System. 


\section{Pendahuluan}

Semua negera sepakat bahwa manusia adalah subjek kunci, pelaku, sekaligus modal utama pembangunan suatu bangsa. Sebagai modal utama pembangunan setiap orang seharusnya memiliki kapabilitas yang memadai. Hanya manusia yang memiliki kapabilitas (kemampuan dan kemauan) yang kuat untuk berkembang maju yang dapat menjadi kunci pembangunan bangsa di masa yang akan datang. Namun, untuk menghasilkan manusia-manusia yang memiliki kapabilitas yang kuat tersebut diperlukan suatu lembaga pendidikan yang mampu menciptakan sumber daya manusia yang berkualitas. Pendidikan adalah proses transformasi dan pembudayaan nilai-nilai tradisional yang luhur dan nilai-nilai baru yang progresif dan ekspresif yang kemudian terakulturasi menjadi tradisi baru yang memiliki kemanfaatan lebih dari yang sebelumnya.

Pendidikan merupakan salah satu aspek penunjang keberhasilan pembangunan, selain itu pendidikan yang telah berkembang juga menggambarkan tingkat kemajuan yang dicapai sebuah bangsa. Indonesia salah satu negara yang sedang berupaya memajukan kualitas pendidikan, salah satu upaya pemerintah untuk memajukan kualitas pendidikan dapat dilihat dari tujuan nasional pendidikan Indonesia yang telah dicanangkan pemerintah dalam (UndangUndang Dasar 1945 Nomor 20 tahun 2003 pasal 1 ayat 1) yang berbunyi pendidikan adalah usaha sadar dan terencana untuk mewujudkan suasana belajar dan proses pembelajaran agar peserta didik secara aktif mengembangkan potensi dirinya untuk memiliki kekuatan spiritual keagamaan, pengendalian diri, kepribadian, kecerdasan, akhlak mulia, serta keterampilan yang diperlukan dirinya, masyarakat, bangsa dan negara.

Salah satu lembaga pendidikan yang berperan penting dalam peningkatan keterampilan (skill) seorang pembelajar yakni lembaga pendidikan vokasional. Pendidikan vokasional berkaitan dengan pengembangan keilmuan yang mempelajari sifat-sifat pekerjaan, aspek pekerjaan, jalur dan jenjang karir kerja melalui pengembangan kompetensi atau skill kerja yang dibutuhkan di dunia kerja. Vokasional konsern pada sifat-sifat pekerjaan. Pada pedagogi vokasional berlangsung proses pembentukan jiwa seseorang agar konsern dan mengapresiasi pekerjaan. Pendidikan vokasional adalah pendidikan untuk mengembangkan skill seseorang sehingga memiliki kapasitas atau kapabilitas untuk melakukan pekerjaan atau jabatan tertentu.

Tradisi pendidikan vokasional bertujuan menyiapkan lulusan untuk bekerja. Persiapan bekerja adalah tujuan utama pendidikan vokasional. Agar siap bekerja maka pendidikan vokasional memuat pelatihan khusus yang cenderung bersifat reproduktif sesuai perintah dosen, guru atau instrukstur dengan fokus perhatian pada pengembangan kebutuhan industri, berisikan skill khusus atau triktrik pasar. Seperti halnya STMIK AKBA adalah salah satu lembaga pendidikan tinggi yang saat ini telah sedang menyelenggarakan pendidikan pada jenjang diploma tiga (D.III) yang memiliki 2 (dua) program studi yakni prodi teknik komputer dan komputerisasi akuntansi, selain itu pada jenjang S1 memiliki program studi sistem informasi dan teknik informatika.

Berbagai kemudahan memperoleh informasi dari berbagai penjuru dunia dapat dinikmati dalam hitungan detik dengan memanfaatkan teknologi dan informasi yang ada. Pada saat teknologi informasi dan komunikasi dianggap sebagai sesuatu yang tidak mungkin, kini telah menjadi kenyataan. Dengan teknologi yang dimanfaatkan dengan baik, maka akan sangat membantu dalam hal manajemen pengolahan data, khususnya dalam dunia pendidikan. Sistem informasi merupakan hal yang harus ada untuk bisa 
bersaing dengan yang lain, seperti halnya manajemen pengolahan data kehadiran dan nilai mahasiswa oleh setiap dosen.

Sistem informasi manajemen pengolahan nilai pada salah satu perguruan tinggi yaitu STMIK AKBA yang merupakan objek penelitian bagi peneliti masih memerlukan manajemen pengolahan yang lebih efektif, cepat dan akurat. Sistem pengolahan nilai mahasiswa pada STMIK AKBA saat ini masih berbasis manual, misalnya proses penginputan data kehadiran mahasiswa dilakukan pada saat setelah final, namun hal ini bisa dilakukan untuk setiap Dosen pada saat masuk mengajar dengan cara melalukan pengabsenan secara rutin pada setiap pertemuan dengan media laptop yang dimiliki oleh masing-masing Dosen mata kuliah dengan login pada akun masing-masing. Hasil perhitungan kehadiran akan langsung masuk ke nilai kehadiran mahasiswa. Penginputan nilai mahasiswa oleh dosen masih dilakukan oleh Bagian Administrasi Akademik dan Kemahasiswaan sehingga informasi nilai bagi mahasiswa masih sering terlambat dan hardcopy yang diserahkan masih sering tercecer/hilang, jika hal tersebut terjadi maka harus di buat ulang oleh Dosen yang bersangkutan. Kriteria penilaian terdiri dari kehadiran $15 \%$, aktivitas (tugas) $45 \%$, mid 20\%, final $20 \%$.

Pengembangan sistem informasi manajemen pengolahan nilai mahasiswa mahasiswa akan lebih cepat dan akurat dalam hal manajemen pengolahan nilai karena setiap dosen pengampuh mata kuliah akan melakukan pengabsenan secara rutin pada setiap pertemuan minimal 14 kali dan maksimal 16 kali pertemuan termasuk mid dan final test. Dosen yang akan melakukan pengabsenan tidak dapat masuk ke halaman daftar hadir mahasiswa sebelum memasukkan materi pokok perkuliahan. Setelah materi pokok perkuliahan tersimpan, maka akan masuk ke halaman absensi mahasiswa. Jika pengolahan absensi telah tersimpan, maka akan masuk ke halaman output yang akan menampilkan materi pokok perkuliahan, daftar mahasiswa yang hadir, sakit, izin dan tanpa keterangan. Hasil rekapan kehadiran mahasiswa secara otomatis akan terkirim ke dalam komponen penilaian yaitu komponen kehadiran, sehingga dosen tidak perlu melakukan penginputan nilai kehadiran pada akhir semester.

\section{Kajian Pustaka}

\subsection{Tinjauan Pustaka}

Tujuan pendidikan vokasional adalah untuk meningkatkan relevansi pendidikan dan bimbingan kejuruan dengan perkembangan masyarakat sejahtera yang kompetitif dan berorientasi kepada pembangunan berkelanjutan. Hal ini sejalan dengan UU Sisdiknas Tahun 2003 menyatakan bahwa visi pendidikan nasional indonesia adalah mewujudkan sistem pendidikan sebagai pranata sosial yang kuat dan berwibawa untuk memberdayakan semua warga negara indonesia agar berkembang menjadi manusia yang berkualitas sehingga mampu dan proaktif menjawab tantang zaman yang selalu berubah.

Berdasarkan tujuan pendidikan vokasional dan visi pendidikan nasional tersebut, maka diperlukan terobosanterobosan baru dalam pemanfaatan teknologi informasi khususnya pada lembaga pendidikan vokasional. STMIK AKBA adalah salah satu lembaga pendidikan tinggi yang telah sedang membina pendidikan pada jenjang diploma tiga. Penguasaan Teknologi informasi harus ditingkatkan dengan baik bagi setiap mahasiswa agar menjadi lulusan yang berkualitas dan berdaya saing global. Penyelenggaraan pendidikan vokasional harus didukung oleh teknologi informasi yang memadai, termasuk pengembangan sistem informasi manajemen pengolahan nilai mahasiswa berbasis web pada STMIK AKBA 
1. Sistem Informasi

Sistem Informasi Sistem informasiadalah seperangkat unsur yang saling terkait atau komponen yang mengumpulkan (input), memanipulasi (proses), menyimpan, dan menyebarkan (output) data dan informasi dan memberikan reaksi korektif (mekanisme umpan balik) untuk memenuhi tujuan (Stair \& Reynolds, 2011). Adapun komponen dari sistem informasi berbasis computer adalah satu set hardware, software, database, telekomunikasi, orang, dan prosedur yang dikonfigurasi untuk mengumpulkan, memanipulasi, menyimpan, dan mengolah data menjadi informasi. Suatu sistem dapat dikatakan sistem informasi jika telah mempunyai semua komponen tersebut. Dengan demikian sistem informasi dapat dikatakan sebagai kombinasi dari teknologi informasi dan aktivitas orang yang menggunakan teknologi untuk mendukung mengumpulkan data, menyimpan, mengelola, mengendalikan dan melaporkan informasi sedemikian rupa sehingga dapat mencapai tujuan yang telah ditetapkan.

2. Pengembangan Sistem Informasi

Untuk mengembangkan suatu sistem informasi, kebanyakan perusahaan menggunakan suatu metodologi yang disebut metodologi pengembangan sistem. Metodologi ini adalah suatu proses standar yang diikuti oleh organisasi untuk melaksanakan seluruh langkah yang diperlukan untuk menganalisis, merancang dan mengimplementasikan dan memelihara sistem informasi (Hoffer dkk, 2005). Seperti yang berlaku pada kebanyakan proses, pengembangan sistem informasi juga memiliki daur hidup. Daur hidupnya disebut daur pengembangan sistem informasi (O'Brien, 2001). Atau secara lebih umum dinamakan SDLC (System Depelopment Life Cycle) atau daur hidup pengembangan sistem.

\section{Hyper Text Markup Language (HTML)}

HTML adalah standar bahasa yang digunakan untuk mengatur penampilan dari halaman web. HTML tersusun atas pasangan-pasangan tag yang mempunyai fungsi yang berbeda-beda. Ciri dari tag pada HTML adalah diawali dengan tanda kurang dari " $<$ " dan diakhiri oleh tanda lebih dari " $>$ " seperti " $<$ head $>$ ". Pada HTML ada 2 macam tag yaitu tag pembuka "<...> dan tag penutup " $<$... >". Sebuah halaman HTML dibagi menjadi 2 bagian yaitu header dan content yang masing-masing diwakili oleh pasangan tag " $<$ head $>\ldots<$ head $>$ " dan " $<$ body $>$.. $<$ /body $>$ ". Header pada HTML berfungsi untuk menyampaikan judul yang diwakili oleh tag " $<$ title $>\ldots<$ title $>$ ". Content pada HTML berisi script yang mengatur tampilan suatu halaman HTML.

4. Hypertext Preprocessor (PHP)

PHP merupakan bahasa pemrograman web-server-side, script yang membuat dokumen HTML secara on the fly, yaitu dokumen HTML yang dihasilkan hanya pada saat diakses oleh user. Sehingga suatu halaman HTML tidak lagi bersifat statis, namun menjadi bersifat dinamis. Sifat server-side ini membuat pengerjaan script tersebut dikerjakan di server sedangkan yang dikirim kepada browser adalah hasil proses dari script tersebut sudah berbentuk HTML. Karena PHP merupakan server-side scripting maka PHP dapat melakukan pengumpulan form data, men-generatedynamic page content atau mengirim dan menerima cookies, dan juga banyak fungsi yang lain. Untuk dapat menjalankan fungsi sebagai server-side scripting maka dibutuhkan PHP parser, webserver, dan webbrowser. Webbrowser perlu dijalankan dan digabungkan dengan instalasi PHP. Untuk mengakses PHP, dapat digunakan web browser yang dapat melihat hasil dari script PHP. 


\section{5. $M y S Q L$}

$M y S Q L$ adalah sebuah aplikasi Relational Database Management Server (RDBMS) yang sangat cepat dan kokoh. Dengan menggunakan MySQL Server maka data dapat diakses oleh banyak pemakai secara bersamaan sekaligus dapat membatasi akses para pemakai berdasarkan privilege (hak akses) yang diberikan. MySQL menggunakan bahasa SQL (Structured Query Language) yaitu bahasa standar yang digunakan untuk pemrograman database. MySQL dipublikasikan sejak 1996, tetapi sebenarnya dikembangkan sejak 1979. MySQL telah memenangkan penghargaan Linux Journal Reader's Choice Award selama tiga tahun. MySQL sekarang tersedia dibawah izin open source, tetapi juga ada izin untuk penggunaan secara komersial.

\subsection{Proses Pengembangan Perangkat Lunak}

Proses pengembangan perangkat lunak yang sering digunakan ialah linear sequential model. Linear Sequential model seperti dijelaskan (Pressman, 2010) merupakan model pengembangan yang terdiri dari beberapa tahapan :

1. Analisis Kebutuhan Perangkat Lunak

2. Desain

3. Implementasi

4. Pengujian

\subsection{Kerangka Pikir}

Diawali dari kebutuhan sisteminformasi manajemen pengolahan data nilai mahasiswa pada STMIK AKBA yang masih menggunakan cara manual khususnya dalam pendataan kehadiran mahasiswa, dalam hal ini dilakukan perekapan nilai kehadiran mahasiswa pada akhir semester sehingga memerlukan waktu yang lama. Selain itu, pengolahan komponen nilai lainnya seperti nilai tugas, nilai mid tes dan nilai final tes. Namun, informasi nilai mahasiswa yang seharusnya diumumkan pada rentang waktu tertentu menjadi terhambat karena setelah proses pengolahan nilai yang dilakukan dosen pengampuh mata kuliah harus diserahkan ke BAAK untuk dilakukan penginputan.

Untuk mengatasi masalah tersebut, maka akan dibangun sistem informasi berbasis web agar lebih mudah diakses oleh mahasiswa maupun Dosen dimana pun dan kapan pun. Dari hasil yang didapat dari analisis kebutuhan akan sistem informasi manajemen pengolahan data nilai mahasiswa, dirancanglah sebuah desain yang sesuai. Dari desain yang dibuat kemudian diimplementasikan, yaitu pada proses inilah berlangsung kegiatan pengembangan perangkat lunak, yaitu pengembangan sistem informasi manajemen pengolahan nilai mahasiswa berbasis web pada STMIK AKBA.

\section{Metode Penelitian}

Metode yang digunakan dalam penelitian ini adalah pendekatan penelitian pengembangan (Research and Development. Metode Research and Development adalah metode penelitian yang digunakan untuk menghasilkan produk tertentu, dan menguji keefektifan produk tersebut (Sugiyono 2009:407). Penelitian ini bertujuan untuk mengetahui kualitas dari suatu sistem informasi yaitu Sistem Informasi Manajemenpengolahan Nilai mahasiswa pada STMIK AKBA. Desain Penelitian mengacu pada model waterfall pada rekayasa perangkat lunak.

\subsection{Model Pengembangan}

Proses pengembangan dilakukan berdasarkan kaidah rekayasa perangkat lunak yaitu linear sequential model atau biasa disebut dengan model waterfall. Berikut tahap-tahap pengembangan perangkat lunak dalam penelitian ini :

1. Analisis Kebutuhan

Dilakukan analisis tentang kebutuhan serta masalah yang dialami dari pihak kampus. Perangkat lunak yang dibuat harus memiliki fungsi-fungsi sesuai dengan kebutuhan seperti yang diinginkan dari pihak sekolah tinggi yaitu STMIK AKBA. 


\section{Tahap Desain (Perancangan)}

Berdasarkan analisis kebutuhan dapat diketahui apa saja fungsi-fungsi yang harus dimiliki perangkat lunak, dan kemudian dibuat rancangan perangkat lunak dengan fungsi yang sesuai. Tahap desain meliputi :

1) Perancangan UML (Unified Modeling Language)

2) Perancangan Database

3) Perancangan Antar Muka (Graphical User Interface)

3. Implementasi

Pada tahapan ini dilakukan pembuatan aplikasi berdasarkan hasil desain. Pembuatan aplikasi menggunakan pemrograman PHP dan database MySQL serta untuk informasi nilai bagi mahasiswa di desain dengan menggunakan bahasa pemrograman php dan perpaduan antara bahasa pemrograman lainnya yang akan menghasilkan sistem informasi berbasis web.

4. Pengujian

Tahap pengujian yaitu proses memastikan bahwa perangkat lunak yang telah dikembangkan layak untuk digunakan oleh pengguna akhir.

\subsection{Uji Coba Produk}

Uji coba produk atau model merupakan bagian yang sangat penting dalam penelitian pengembangan, yang dilalukan setelah rancangan produk selesai, dengan tujuan untuk melihat sejauhmana produk yang dibuat mencapai suatu sasaran atau tujuan serta untuk mengetahui apakah produk yang dihasilkan layak digunakan atau belum. Ada dua kriteria yang harus dipenuhi oleh sebuah produk, yaitu kriteria fungsi atau isi produk (instructional criteria) dan kriteria tampilan (presentation criteria).

Uji coba produk dilakukan pada penelitian ini adalah pengujian kualitas dari sistem. Uji coba sistem dilakukan dalam tiga tahapan, yaitu

1. Uji terbatas, dilakukan oleh admin baak sebagai pihak yang bertanggung jawab pada penggunaan sistem. Informan yang digunakan pada uji ini sebanyak 2 orang admin. Pengujian ini berupa valiidasi terhadap tampilan dan keefektifan dari produk sistem informasi. Hasil validasi dari pengujian terbatas ini menjadi masukan dan referensi untuk perbaikan sistem informasi yang diperlukan.

2. Uji coba lapangan (Field Testing) dilakukan setelah pengujian atau validasi sebelumnya telah terpenuhi. Produk sistem informasi diuji oleh calon pengguna yaitu dosen dan mahasiswa. Informan yang digunakan pada uji ini adalah ahli sebanyak 2 orang, dosen sebanyak 10 orang, mahasiswa sebanyak 20 orang dan admin BAAK STMIK AKBA sebanyak 2 orang. Pengujian lapangan dilakukan untuk menjaring pendapat informan tentang aktivitas sistem, tampilan, tingkat kemudahan serta kelebihan dan kekurangan dari sistem.

\subsection{Instrumen Penelitian}

Menurut Sugiyono (2009:148) "Instrumen penelitian adalah suatu alat yang digunakan untuk mengukur fenomena alam maupun sosial yang diamati". Dalam penelitian ini, penulis menggunakan Faktor Kualitas McCall sebagai alat ukur/instrumen dalam menentukan tingkat kelayakan perangkat lunak Sistem Informasi Pengolahan Nilai Mahasiswa Berbasis Web. Adapun indikator yang dipilih adalah dari segi Correctness, Reliability, Integrity, dan Usability

1. Correctness (Kebenaran)

Indikator ini dipilih untuk mengetahui sejauh mana perangkat lunak mampu memenuhi kebutuhan pelanggan. Dari indikator ini dipilih dua kriteria penilaian yaitu Completeness dan Concistency.

a. Completeness (Kelengkapan)

Kriteria ini dipilih untuk mengetahui sejauh mana perangkat lunak mampu menyediakan fasilitas yang lengkap dalam membantu pengolahan nilai 
mahasiswa oleh Dosen STMIK

AKBA.

b. Concistency (Konsisten)

Kriteria ini dipilih untuk mengetahui sejauh mana perangkat lunak mampu memberikan desain tampilan yang konsisten sehingga tidak menyulitkan pengguna.

2. Reliability (Reliabilitas)

Indikator ini dipilih untuk mengetahui sejauh mana perangkat lunak mampu melakukan fungsi yang telah ditetapkan dengan ketelitian yang diminta. Dari indikator ini dipilih tiga kriteria penilaian yaitu Accuracy, Error Tolerance, dan Simplicity.

a. Accuracy (Ketepatan)

Kriteria ini dipilih untuk mengetahui sejauh mana perangkat lunak mampu melakukan fungsinya secara tepat dan akurat.

b. Error Tolerancy (Toleransi Kesalahan)

Kriteria ini dipilih untuk mengetahui sejauh mana ketahanan sistem terhadap kesalahan program.

c. Simplicity (Kesederhanaan)

Kriteria ini dipilih untuk mengetahui sejauh mana Sistem Informasi Pengolahan Nilai Mahasiswa Berbasis Web ini dapat dipahami oleh pengguna tanpa kesukaran.

3. Integrity (Integritas)

Indikator ini dipilih untuk mengetahui kemampuan perangkat lunak dalam mengontrol akses data oleh pengguna yang tidak berhak. Dari indikator ini dipilih dua kriteria penilaian yaitu Instrumentation dan Security.

a. Instrumentation (Instrumentasi)

Kriteria ini dipilih untuk mengetahui sejauh mana kemampuan Sistem Informasi Pengolahan Nilai Mahasiswa Berbasis Web dalam memonitor operasi yang dilakukan serta menentukan kesalahan yang terjadi.

b. Security (Keamanan)

Kriteria ini dipilih untuk mengetahui sejauh mana kemampuan Sistem Informasi Pengolahan Nilai Berbasis Web dalam mengontrol dan melindungi data.

4. Usability (Usabilitas)

Indikator ini dipilih untuk mengetahui sejauh mana perangkat lunak memberikan kemudahan pengoperasian bagi pengguna. Dari indikator ini dipilih dua kriteria penilaian yaitu Operability dan Training.

a. Operability (Operabilitas)

Kriteria ini dipilih untuk mengetahui sejauh mana kemudahan pengoperasian Sistem Informasi Pengolahan Nilai Berbasis Web oleh pengguna.

b. Training (Pelatihan)

Kriteria ini dipilih untuk mengetahui tingkat ketersediaanlayanan petunjuk bagi pengguna baru.

Tabel 1. Indikator dan Butir Kriteria Instrumen Penelitian

\begin{tabular}{l|l|l}
\hline Indikator & Butir Kriteria & Penjelasan Singkat \\
\hline \multirow{3}{*}{ Correctness } & Completeness & Implementasi dari fungsi yang tercapai \\
\cline { 2 - 3 } & Consistency & Kesamaan desain dan pengembangan perangkat lunak \\
\hline Integrity & Accuracy & Ketepatan komputasi dan kontrol \\
\cline { 2 - 3 } & Error Tolerance & Ketahanan sistem saat terjadi kesalahan \\
\cline { 2 - 3 } & Simplicity & Tingkat dimana program dapat dipahami tanpa kesukaran \\
\cline { 2 - 3 } & Security & $\begin{array}{l}\text { Tingkat dimana program memonitor operasinya sendiri dan } \\
\text { menentukan kesalahan yang terjadi }\end{array}$ \\
\hline Usability & Operability & $\begin{array}{l}\text { Ketersediaan mekanisme yang mengontrol atau melindungi } \\
\text { program atau data }\end{array}$ \\
\cline { 2 - 3 } & Training & Tingkat kemudahan pengoperasian program \\
\hline
\end{tabular}

(Sumber : McCall, 1977) 


\subsection{Teknik Analisis Data}

Teknik analisis data menggunakan deskriptif kuantitatif yaitu memaparkan produk hasil rekayasa perangkat lunak dan menguji tingkat kelayakan produk. Tingkat kelayakan perangkat lunak diukur melalui persamaan Faktor Kualitas McCall, seperti berikut:

$F q=c 1 \times m 1+c 2 \times m 2+\ldots+c n \times m n$

$\mathrm{Fq}=$ faktor kualitas perangkat lunak $\mathrm{cn}=$ koefisien regresi (bobot)

$\mathrm{mn}=$ metrik yang mempengaruhi perangkat lunak

Nilai Faktor Kualitas $(F q)$ yang diperoleh dari perhitungan kemudian diubah dalam bentuk persentase (\%). Besarnya persentase dihitung dengan persamaan berikut:

$$
\text { Persentase }=\frac{\text { nilai yang didapat }}{\text { nilai maksimum }} \times 100 \%
$$

Selanjutnya, dari lima kategori dibuat skala menurut Suharsimi Arikunto (2008:35), pembagian skala ini hanya dengan memperhatikan rentangan bilangan. Kondisi maksimal yang diharapkan adalah $100 \%$. Antara nilai $1 \%$ sampai dengan $100 \%$ dibagi rata sehingga menghasilkan kategori kelayakan seperti berikut:

Table 2. Kategori Kelayakan

\begin{tabular}{c|l|c}
\hline No. & \multicolumn{1}{|c|}{ Kategori } & $\begin{array}{c}\text { Skor dalam } \\
\text { persentase }\end{array}$ \\
\hline 1 & Sangat Layak & $81 \%-100 \%$ \\
\hline 2 & Layak & $61 \%-80 \%$ \\
\hline 3 & Cukup Layak & $41 \%-60 \%$ \\
\hline 4 & Tidak Layak & $21 \%-40 \%$ \\
\hline 5 & Sangat Tidak Layak & $<21 \%$ \\
\hline
\end{tabular}

\subsection{Teknik Pengujian}

1. Pengujian White-Box

2. Black Box Testing

3.Pengujian Alpha dan Beta

\section{Hasil dan Pembahasan}

\subsection{Hasil Penelitian}

1. Analisis Kebutuhan

Informasi yang baik dapat diperoleh dengan menggunakan sistem informasi yang terpadu dan terstruktur. Analisis kebutuhan sistem merupakan dasar untuk memperbaiki segala kekurangan dari system yang ada sehingga system yang baru dapat memberikan informasi yang cepat dan tepat. Berdasarkan hasil obeservasi yang telah dilakukan dapat diuraikan kebutuhan pengguna yaitu :

a. Sistem Informasi Manajemen Pengolahan Nilai Mahasiswa Berbasis Web yang sudah terkomputerisasi dan mampu mengolah data mata kuliah, dosen dan mahasiswa serta pengolahan data nilai mahasiwa.

b. Sistem Informasi Manajemen Pengolahan Nilai Mahasiswa Berbasis Web dapat menjamin keamanan data.

2. Desain Produk

Desain dibuat langkah-langkah yang dilakukan sebelum membuat sistem informasi. Berikut ini adalah desain dari sistem informasi manajemen pengolahan nilai mahasiswa berbasis web.

a. Jenis Aplikasi Sistem

Sistem aplikasi ini yang digunakan dalam pengembangan sistem informasi manajemen pengolahan nilai mahasiswa berbasis web pada STMIK AKBA menggunakan bahasa pemrograman php dan database mysql.

b. Unified Modelling Language (UML)

Dalam pengembangan sistem informasi manajemen pengolahan nilai mahasiswa berbasis web pada STMIK AKBA, menggunakan metode UML. Metode UML merupakan metode object oriented programming (OOP) atau pemrograman berorientasi objek yang menggunakan notasi grafis dalam menyatakan suatu desain. 


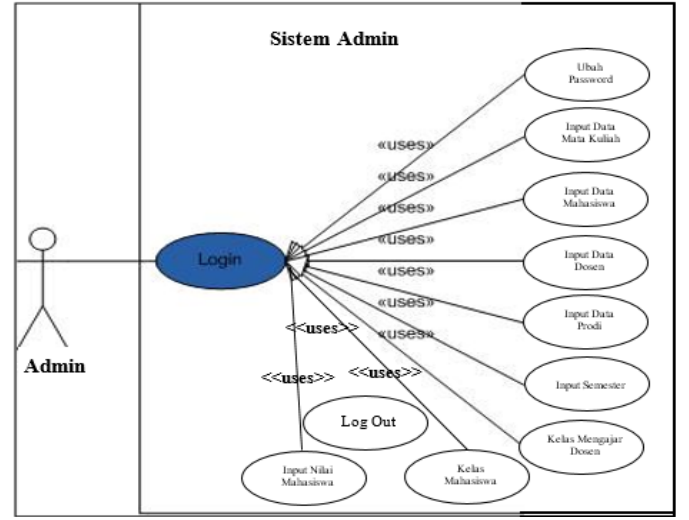

Gambar 1. Use Case Diagram Admin

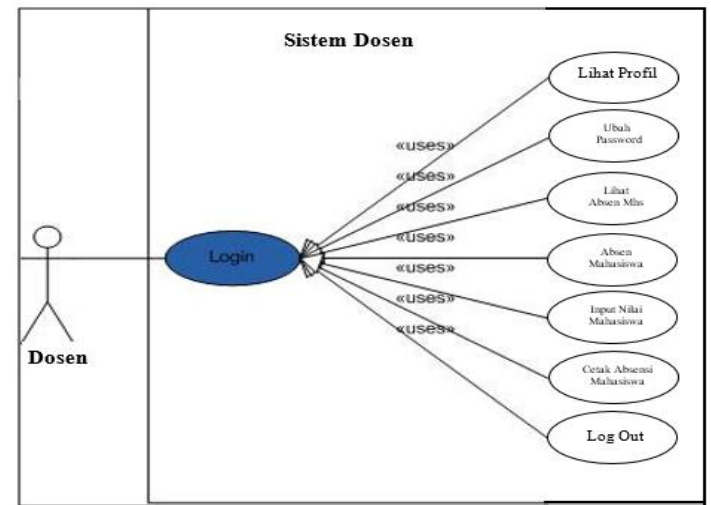

Gambar 2. Use Case Diagram Dosen

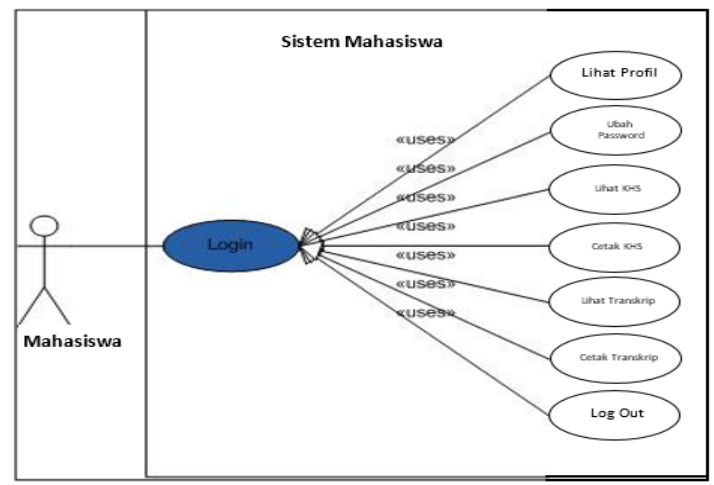

Gambar 3. Use Case Diagram Mahasiswa

3. Pembuatan Produk

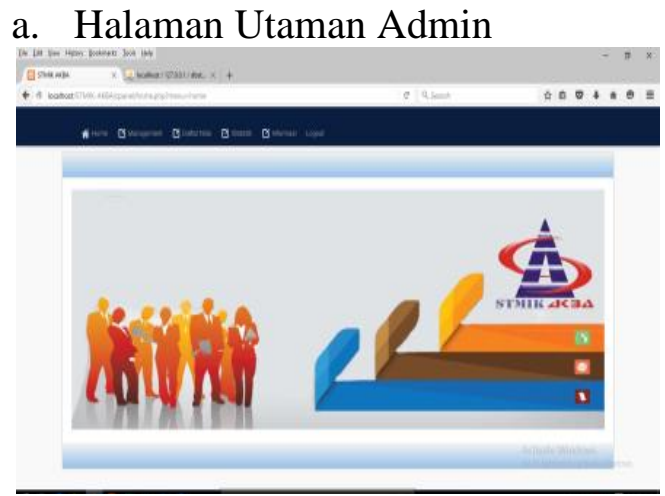

Gambar 4. Halam Utama Admin b. Halaman Input Data Mata Kuliah

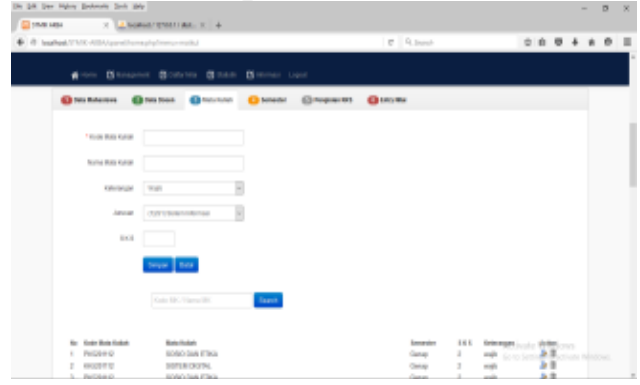

Gambar 5. Halaman Input Data Mata Kuliah

c. Halaman Input Data Dosen

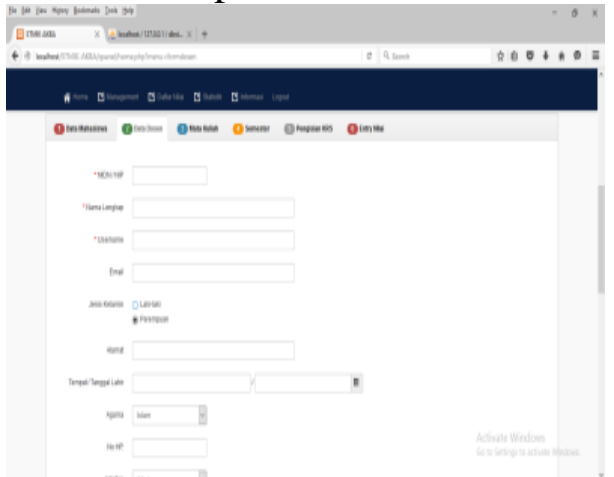

Gambar 6. Halaman Input Data Dosen

d. Halaman Input Nilai

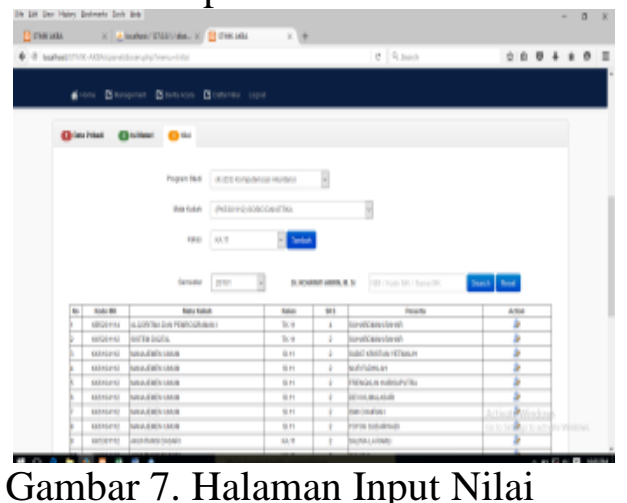

e. Halaman Cetak KHS

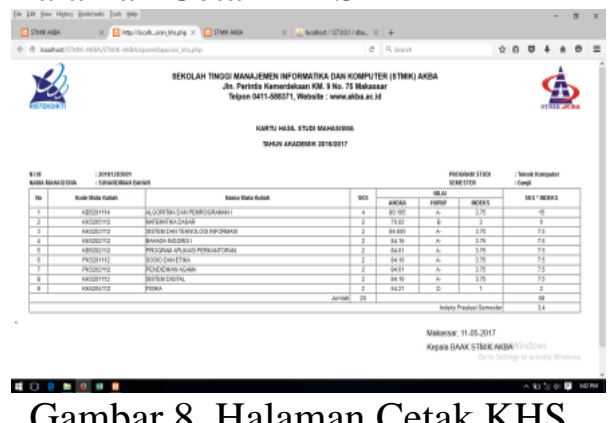

Gambar 8. Halaman Cetak KHS 
4. Uji Coba Produk

Perangkat lunak yang selesai dibuat selanjutnya diuji keseluruhan fungsifungsi dan prosedur yang terdapat dalam perangkat lunak tersebut. Pengujian ini dilakukan untuk memastikan bahwa perangkat lunak benar-benar siap untuk diuji cobakan kepada pengguna. Adapun pengujian yang dilakukan yaitu pengujian dengan metode black and white box testing serta pengujian

a. Dosen

Tabel 3. Data Nilai Kalayakan oleh Dosen alpha dan beta untuk memastikan tingkat kelayakan produk yang dihasilkan.

5. Validasi Produk

Sistem informasi yang dibuat dikonsultasikan kepada ahli rekayasa perangat lunak, dan mendapat penilaian serta saran untuk memperbaiki sistem yang dibuat. Berikut ini adalah penilaian terhadap sistem informasi yang telah dibuat.

\begin{tabular}{|c|c|c|c|c|c|c|c|c|c|c|}
\hline \multirow{2}{*}{ No. } & \multirow{2}{*}{ Nama Responden } & \multicolumn{2}{|c|}{ Correctness } & \multicolumn{3}{|c|}{ Reliability } & \multicolumn{2}{|c|}{ Integrity } & \multicolumn{2}{|c|}{ Usability } \\
\hline & & $C_{p}$ & Cs & $\mathbf{A c}$ & Er & Sm & In & Sc & $O_{p}$ & Tr \\
\hline 1 & Ashari, S.T., M. T & 10 & 8 & 9 & 10 & 10 & 8 & 10 & 8 & 10 \\
\hline 2 & Muhajirim, S. Kom., M. T & 10 & 8 & 10 & 10 & 8 & 10 & 8 & 8 & 10 \\
\hline 3 & Erwin Gatot, S. Kom. M. Kom & 6.7 & 6 & 8 & 6 & 6 & 8 & 6 & 8 & 6 \\
\hline 4 & Listia Utami, S. Pd., M. Pd & 9.3 & 8 & 9 & 10 & 8 & 10 & 8 & 10 & 10 \\
\hline 5 & Muhammad Arafah, S. Kom., M. T & 8 & 6 & 7 & 10 & 8 & 8 & 8 & 6 & 8 \\
\hline 6 & Wabdillah, S. Pd., M. Pd & 10 & 8 & 9.5 & 10 & 8 & 10 & 10 & 10 & 8 \\
\hline 7 & Dra. Ratnawati, M. Si & 7.3 & 8 & 6.5 & 8 & 10 & 6 & 8 & 8 & 6 \\
\hline 8 & Neneng Awaliah, S. E., M. M & 9.3 & 10 & 10 & 8 & 8 & 8 & 10 & 10 & 10 \\
\hline 9 & First Wanita, S. Kom., M. Kom & 6.7 & 6 & 7 & 8 & 6 & 8 & 8 & 6 & 8 \\
\hline 10 & Amran, S. Pd., M. Pd & 9.3 & 8 & 9.5 & 10 & 10 & 10 & 8 & 10 & 8 \\
\hline
\end{tabular}

b. Mahasiswa

Tabel 4. Data Nilai Kalayakan oleh Mahasiswa

\begin{tabular}{|c|c|c|c|c|c|c|c|c|c|c|}
\hline $\mathrm{Ma}$ & Mimm Femponden & \multicolumn{2}{|c|}{ Compectuen } & \multicolumn{3}{|c|}{ Eefinbilits } & \multicolumn{2}{|c|}{ Inteprity } & \multicolumn{2}{|c|}{ Unabifiry } \\
\hline 1 & 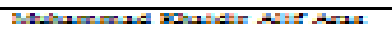 & 5 & 5 & $\mathbf{B}$ & $\bar{B}$ & $\Xi$ & 5 & 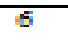 & 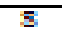 & 5 \\
\hline 3 & PEna Itome' & 10 & 10 & 9 & 10 & 10 & 10 & $\overline{3}$ & 10 & 10 \\
\hline 4 & Ays Papta San & 9 & 10 & 35 & 10 & 10 & 10 & 3 & 10 & $\Xi$ \\
\hline$\leq$ & Panei Lamayana & 19 & $\overline{3}$ & 95 & 18 & 5 & 3 & 5 & 10 & 10 \\
\hline I & 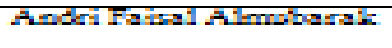 & 93 & 15 & 95 & 10 & 15 & 18 & 10 & 10 & 10 \\
\hline 3 & Noerhidayab Bt & Es & 15 & 95 & 5 & 10 & 5 & 10 & 10 & 10 \\
\hline 9 & Mardiana & 35 & 10 & 9 & 3 & 5 & 10 & 5 & 10 & 10 \\
\hline 10 & Hef Sopriad & 5 & 10 & 9 & 10 & 10 & 10 & 10 & 10 & 5 \\
\hline 13 & What Fats Aothar & 10 & 3 & 93 & 3 & 10 & 10 & 3 & In & 10 \\
\hline $1+$ & Iahmi Ides & 3 & 3 & 35 & $\overline{8}$ & 10 & 3 & 10 & $\overline{3}$ & 10 \\
\hline 15 & Furitud betrgant & $\overline{3}$ & $\overline{3}$ & 9 & 10 & 5 & 10 & $\overline{3}$ & 10 & 5 \\
\hline 15 & Boparman & 75 & 5 & 5s & 5 & 5 & 5 & 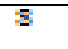 & $\Xi$ & 5 \\
\hline 17 & Horiblema lasmir & ES & $\Xi$ & 95 & 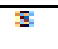 & 3 & 5 & $\Xi$ & $\$$ & 10 \\
\hline 13 & Bgament Fimal & 35 & $\overline{3}$ & 95 & $\overline{3}$ & 10 & 10 & 5 & $\overline{5}$ & 10 \\
\hline 19 & Mrer Intan Syakbani & 19 & $\$$ & 10 & 3 & 3 & 18 & 15 & 3 & 18 \\
\hline 10 & Werma & 93 & 10 & 55 & 10 & 10 & 10 & 5 & 10 & 5 \\
\hline
\end{tabular}


6. Reabilitas Data

Pengguna yang dilibatkan dalam penelitian ini terdiri dari 10 orang Dosen dan 20 orang mahasiswa. Hasil uji reliabilitas instrument berupa angket kepada yaitu dosen dan mahasiswa akan di olah secara sistematis agar dapat menghasilkan data yang akurat dalam menentukan kelayakan penggunaan perangkat lunak sistem informasi manajemen pengolahan nilai yang telah dikembangkan oleh peneliti pada STMIK AKBA.

a. Dosen

Pada penelitian ini, dosen memiliki peran yang sangat penting karena sistem informasi ini dikembangkan untuk memudahkan dosen dalam hal manajemen pengolahan nilai mahasiswa. Adapun data hasil kuisioner instrumen berupa angket oleh pengguna (dosen) dapat dilihat pada tabel 5 .

\section{a. Dosen}

Tabel 5. Hasil kuisioner instrument berupa angket oleh Dosen

\begin{tabular}{|c|c|c|c|c|c|c|c|c|c|c|c|c|c|c|c|c|}
\hline \multirow{2}{*}{$\begin{array}{c}\text { No. } \\
\text { Resp. }\end{array}$} & \multicolumn{14}{|c|}{ Jawaban Angket } & \multirow[b]{2}{*}{$\Sigma \mathrm{X}_{\mathrm{r}}$} & \multirow{2}{*}{$\left(\Sigma X_{H}\right)^{2}$} \\
\hline & 1 & 2 & 3 & 4 & 5 & 6 & 7 & 8 & 9 & 10 & 11 & 12 & 13 & 14 & & \\
\hline 1 & 5 & 5 & 5 & 4 & 4 & 5 & 4 & 5 & 5 & 5 & 4 & 5 & 4 & 5 & 65 & 4225 \\
\hline 2 & 5 & 5 & 5 & 4 & 5 & 5 & 5 & 5 & 5 & 4 & 5 & 4 & 4 & 5 & 66 & 4356 \\
\hline 3 & 4 & 3 & 3 & 3 & 4 & 4 & 3 & 5 & 3 & 3 & 4 & 3 & 4 & 3 & 49 & 2401 \\
\hline 4 & 5 & 4 & 5 & 4 & 4 & 5 & 4 & 5 & 5 & 4 & 5 & 4 & 5 & 5 & 64 & 4096 \\
\hline 5 & 4 & 4 & 4 & 3 & 3 & 3 & 4 & 4 & 5 & 4 & 4 & 4 & 3 & 4 & 53 & 2809 \\
\hline 6 & 5 & 5 & 5 & 4 & 5 & 4 & 5 & 5 & 5 & 4 & 5 & 5 & 5 & 4 & 66 & 4356 \\
\hline 7 & 4 & 4 & 3 & 4 & 3 & 3 & 3 & 4 & 4 & 5 & 3 & 4 & 4 & 3 & 51 & 2601 \\
\hline 8 & 5 & 4 & 5 & 5 & 5 & 5 & 5 & 5 & 4 & 4 & 4 & 5 & 5 & 5 & 66 & 4356 \\
\hline 9 & 3 & 4 & 3 & 3 & 4 & 3 & 3 & 4 & 4 & 3 & 4 & 4 & 3 & 4 & 49 & 2401 \\
\hline 10 & 4 & 5 & 5 & 4 & 5 & 5 & 4 & 5 & 5 & 5 & 5 & 4 & 5 & 4 & 65 & 4225 \\
\hline$\sum \mathbf{X}_{\mathbf{V}}$ & 44 & 43 & 43 & 38 & 42 & 42 & 40 & 47 & 45 & 41 & 43 & 42 & 42 & 42 & 594 & 35826 \\
\hline$\sum \mathbf{X}_{V^{2}}$ & 198 & 189 & 193 & 148 & 182 & 184 & 166 & 223 & 207 & 173 & 189 & 180 & 182 & 182 & 2596 & \\
\hline
\end{tabular}

\section{b. Mahasiswa}

Selanjutnya pengguna yang dilibatkan dalam penelitian ini terdiri dari 20 orang mahasiswa. Adapun data hasil uji realibilitas instrumen berupa angket oleh pengguna (mahasiswa) dapat dilihat pada tabel 6 .

Tabel 6. Hasil kuisioner instrument berupa angket oleh Mahasiswa

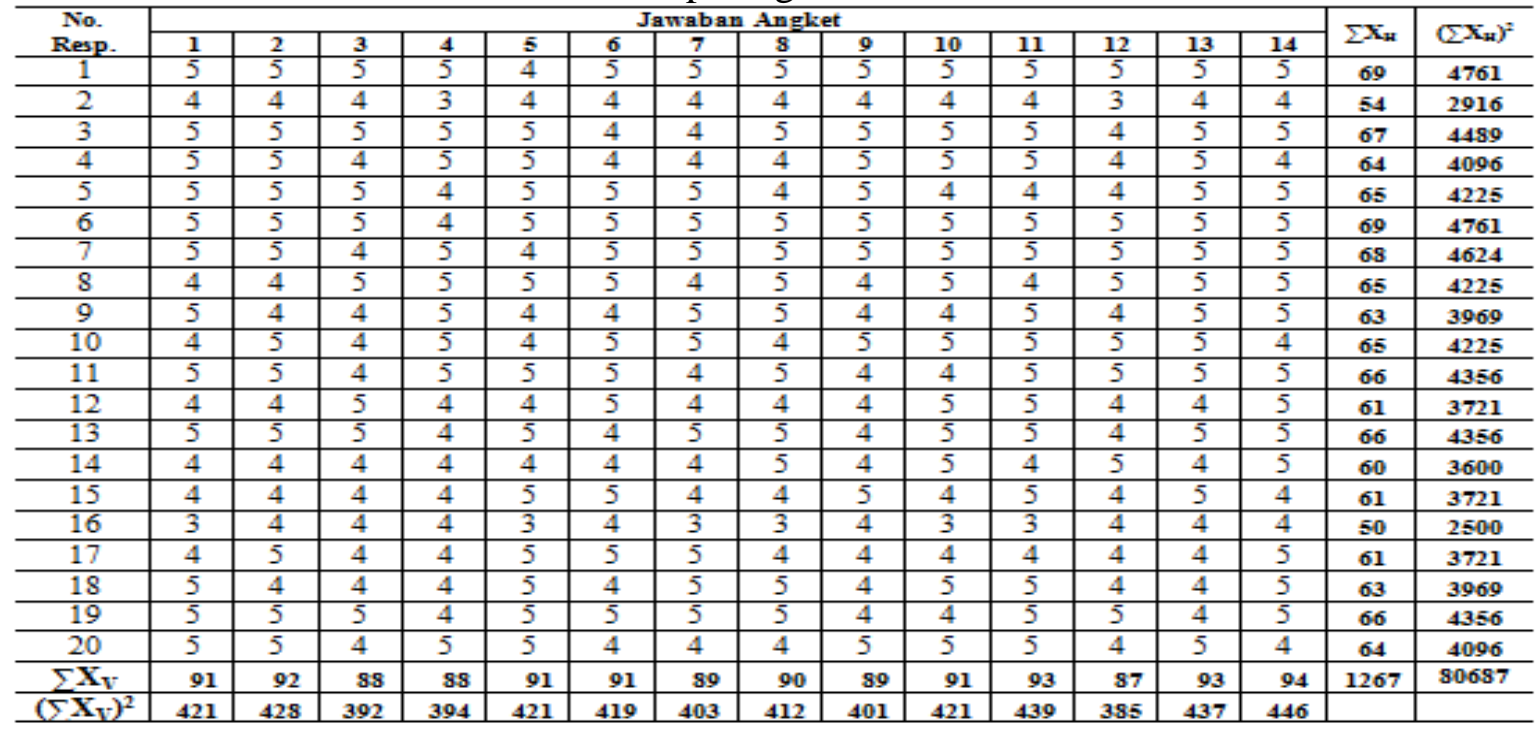




\subsection{Pembahasan}

Data yeng telah diperoleh dari hasil pengujian kelayakan perangkat lunak, selanjutnya diteliti tingkat kelayakan Sistem Informasi Manajemen Pengolahan Nilai Mahasiswa Berbasis Web pada STMIK AKBA ini. Tingkat kelayakan perangkat lunak dihitung berdasarkan masing-masing indikator dengan menggunakan rumus:

$F_{q}=c_{1} \cdot m_{1}+c_{2} \cdot m_{2}+\ldots+c_{n} \cdot m_{n}$

Adapun bobot untuk setiap kriteria indikator dapat dilihat pada tabel berikut:

Tabel 7. Bobot Kriteria Indikator

\begin{tabular}{l|l|c}
\hline Indikator & \multicolumn{1}{|c|}{ Kriteria } & $\begin{array}{c}\text { Bobot } \\
(\mathbf{0 - 1})\end{array}$ \\
\hline \multirow{2}{*}{ Correctness } & Completeness & 1 \\
\cline { 2 - 3 } & Consistency & 0,8 \\
\hline \multirow{2}{*}{ Reliability } & Accuracy & 1 \\
\cline { 2 - 3 } & Error Tolerance & 0,8 \\
\cline { 2 - 3 } & Simplicity & 0,8 \\
\hline \multirow{2}{*}{ Integrity } & Instrumentation & 0,8 \\
\cline { 2 - 3 } & Security & 1 \\
\hline & Operability & 0,8 \\
\cline { 2 - 3 } & Training & 0,8 \\
\hline
\end{tabular}

(Sumber : McCall, 1977)

Nilai bobot ditetapkan dengan nilai terendah adalah 0 dan nilai tertinggi adalah 1. Berdasarkan tabel 7 nilai bobot untuk kriteria Completeness, Accuracy, dan Security adalah 1 . Hal ini menunjukkan bahwa kriteria tersebut merupakan elemen penting dalam pengembangan perangkat lunak Sistem Informasi Manajemen Pengolahan Nilai Berbasis Web pada STMIK AKBA.

Penghitungan tingkat kelayakan oleh pengguna menggunakan rumus yang sama dengan penghitungan tingkat kelayakan oleh ahli. Penghitungan dilakukan terhadap masing-masing indikator.

a. Correctness

1) Dosen

Dari perhitungan data Dosen, selanjutnya dilakukan penggolongan hasil perhitungan ke dalam kategori kelayakan, yaitu: sebanyak 7Orang Dosen menyatakan Sangat Layak dan 3
Orang Dosen menyatakan Layak. Jadi dapat disimpulkan bahwa mayoritas Dosen (70\%) menyatakan Sistem Informasi Manajemen Pengolahan Nilai Mahasiswa Berbasis Web pada STMIK AKBA ini Sangat Layak dari segi Reliability.

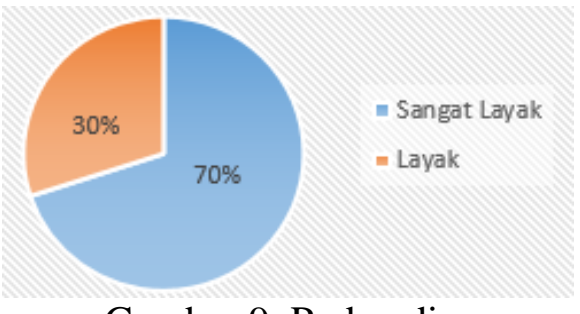

Gambar 9. Perbandingan

Kelayakan dari segi Reliability oleh Dosen

2) Mahasiswa

Sebanyak 18Orang Mahasiswa menyatakan Sangat Layak dan 2Orang Mahasiswa menyatakan Layak Jadi dapat disimpulkan bahwa mayoritas Mahasiswa (90\%) menyatakan Sistem Informasi Manajemen Pengolahan Nilai Mahasiswa Berbasis Web pada STMIK AKBA ini Sangat Layak dari segi Reliability.

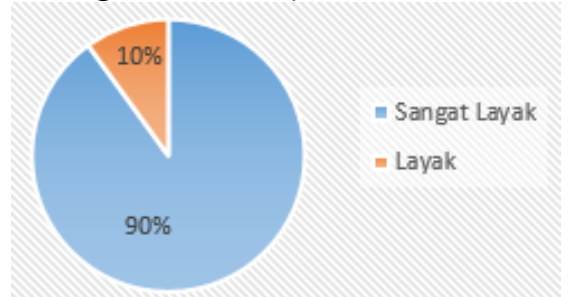

Gambar 10. Perbandingan

Kelayakan dari segi Reliability oleh Mahasiswa

b. Integrity

1) Dosen

Sebanyak6Orang Dosen menyatakan Sangat Layak dan 4Orang Dosen menyatakan Layak. Jadi dapat disimpulkan bahwa mayoritas Dosen (60\%) menyatakan Sistem Informasi Manajemen Pengolahan Nilai Mahasiswa Berbasis Web pada STMIK AKBA ini Sangat Layak dari segi Integrity. 


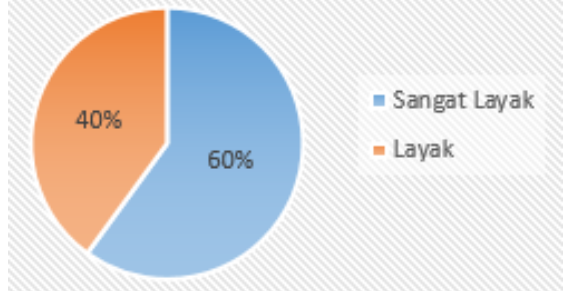

Gambar 11. Perbandingan Kelayakan dari segi Integrity oleh Dosen

2) Mahasiswa

Sebanyak 16Orang Mahasiswa menyatakan Sangat Layak dan 4Orang Mahasiswa menyatakan Layak. Jadi dapat disimpulkan bahwa mayoritas Mahasiswa (80\%) menyatakan Sistem Informasi Manajemen Pengolahan Nilai Mahasiswa Berbasis Web pada STMIK AKBA ini Sangat Layak dari segi Integrity.

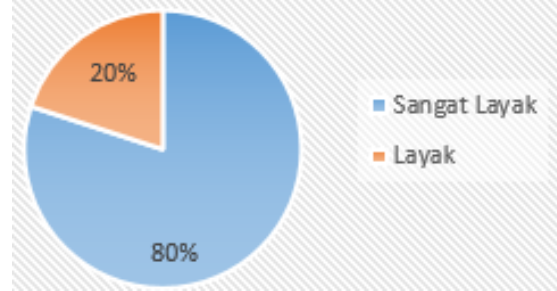

Gambar 12. Perbandingan

Kelayakan dari segi Integrity oleh Mahasiswa

c. Usability

1) Dosen

Sebanyak 6Orang Dosen menyatakan Sangat Layak dan 4Orang Dosen menyatakan Layak. Jadi dapat disimpulkan bahwa mayoritas Dosen (60\%) menyatakan Sistem Informasi Manajemen Pengolahan Nilai Mahasiswa Berbasis Web pada STMIK AKBA ini Sangat Layak dari segi Usability.

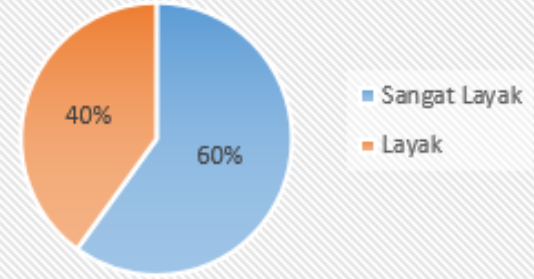

Gambar 13. Perbandingan Kelayakan dari segi Usability oleh Dosen
2) Mahasiswa

Sebanyak 18Orang Mahasiswa menyatakan Sangat Layak dan 2Orang Mahasiswa menyatakan Layak. Jadi dapat disimpulkan bahwa mayoritas Mahasiswa (90\%) menyatakan Sistem Informasi Manajemen Pengolahan Nilai Mahasiswa Berbasis Web pada STMIK AKBA ini Sangat Layak dari segi Usability.

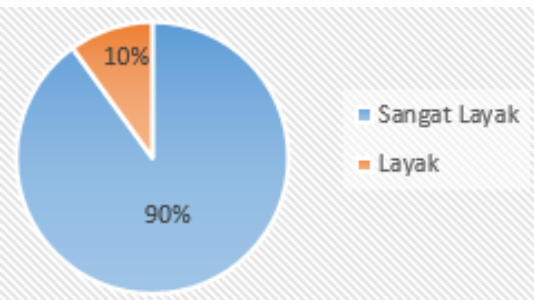

Gambar 14. Perbandingan Kelayakan dari segi Usability oleh Mahasiswa

\section{Kesimpulan dan Saran}

\subsection{Kesimpulan}

Berdasarkan hasil penelitian dan pembahasan, maka kesimpulan yang dapat diambil dari penelitian ini adalah sebagai berikut:

1. Perangkat lunak Sistem Informasi Pengolahan Nilai Mahasiswa Berbasis Web pada STMIK AKBA ini telah berhasil dikembangkan. Sistem ini mampu mengelola data pengajaran Dosen khususnya pengolahan nilai mahasiswa secara cepat dan tepat.

2. Berdasarkan penilaian kelayakan perangkat lunak oleh ahli, tingkat kelayakan Sistem Informasi Pengolahan Nilai Mahasiswa Berbasis Web pada STMIK AKBA dari segi correctness adalah sebesar 85,55\% (sangat layak), dari segi reliability adalah sebesar $83,84 \%$ (sangat layak), dari segi integrity adalah sebesar $80 \%$ (layak), dan dari segi usability adalah sebesar $80 \%$ (layak). Sedangkan berdasarkan penilaian kelayakan perangkat lunak oleh pengguna, dapat disimpulkan sebanyak 60\% Dosendan $80 \%$ mahasiswa menyatakan bahwa 
Sistem Informasi Pengolahan Nilai Mahasiswa Berbasis Web pada STMIK AKBAini sangat layak dari segi correctness,. Dari segi reliability, sebanyak 70\% Dosen dan 90\% mahasiswa menyatakan bahwa Sistem Informasi Pengolahan Nilai Mahasiswa Berbasis Web pada STMIK AKBA ini sangat layak. Dari segi integrity, sebanyak 60\% Dosen dan sebanyak $80 \%$ mahasiswa menyatakan bahwa Sistem Informasi Pengolahan Nilai Mahasiswa Berbasis Web pada STMIK AKBA ini sangat layak,. Dari segi usability, sebanyak $60 \%$ Dosen dan $90 \%$ mahasiswa menyatakan bahwa Sistem Informasi Manajemen Pengolahan Nilai Mahasiswa Berbasis Web pada STMIK AKBA ini sangat layak.

\subsection{Saran}

Saran-saran yang dapat peneliti berikan yang sekiranya bermanfaat adalah sebagai berikut:

1. Perlu adanya penambahan beberapa fitur seperti animasi flashyang akan membuat sistem informasi ini lebih menarik dan komunikatif.

2. Prosedur pengolahan data nilai yang ada pada penelitian ini adalah berdasar pada Semester 2016/2017 ganjil, jadi apabila terjadi perubahan prosedur pengolahan data nilai mahasiswa pada STMIK AKBA termasuk pada kriteria penilaian maka perlu dilakukan perubahan ataupun penyesuaian prosedur pada perangkat lunak.

3. Sistem Informasi Manajemen Pengolahan Nilai Mahasiswa ini dapat dipadukan dengan sistem informasi yang ada dilingkungan STMIK AKBA seperti Website STMIK AKBAsehingga akan menghasilkan satu kesatuan sistem informasi kampus yang interaktif.

\section{Referensi}

[1] Aprianto, Bowo. 2011. Perancangan dan Pengembangan Web Program
Presensi Siswa SMP Yayasan Pupuk Kaltim Berbasis Php dengan Framework Codeigniter. Yogyakarta : Sekolah Tinggi Ilmu Manajemen Informatika dan Komputer Amikom.

[2] Gall, M.D., Gall, J.P., dan Borg, W.R.. 2003. Educational Research: An Introduction (7th Edition). United State of America : Pearson Education. Inc.

[3] Hakim, Lukmanul. 2015. Rahasia Inti Master PHP \& MySQLi (Improve). Yogyakarta : $\mathrm{CV}$. LOKOMEDIA.

[4] Hartadi, Lupiyo. 2012. Analisis dan Pengembangan Sistem Informasi Akademik Siswa berbasis web menggunakan php dan MySQL pada SMAN 1 Tayu. Yogyakarta : Universitas Negeri Yogyakarta.

[5] Hoffer, dkk. Modern Database Management. Sevent Edition. Prentice Hall.

[6] Jalaluddin Asep. (2010)."Perancangan Sistem Informasi Akademik Dan Kemahasiswaan (Siak) Versi 1.0 Menggunakan Visual Foxpro 6.0". Tangerang. Amik Wahana Mandiri.

[7] Jogianto, 2005. Analisis dan Desain Sistem Informasi. Yogyakarta : ANDI.

[8] Kadir, Abd. 2008. Dasar Pemrograman Web Dinamis Menggunakan Web. Yogyakarta : ANDI.

[9] Kadir, Abd. 2014. Pengenalan Sistem Informasi Edisi Revisi. Yogyakarta : ANDI.

[10] Lewis. 1995. Usability Satisfaction Questionnaires : Psychometric Evaluation and Instructions for Use.

[11] McCall, dkk. 1977.Factors in Software QualityTehnical Report RADC-TR-77-369, US Department of Commerce.

[12] Nugroho, Irwin. 2011. Sistem Informasi Penerimaan Siswa Baru Berbasis PHP dan MySQL. 
Yogyakarta : Universitas Negeri Yogyakarta

[13] O’Brien, James. 2001. Pengenalan Sistem Informasi (Introduction to Information System). New York : McGraw-Hill.

[14] Pressman, R. (2002). Rekayasa Perangkat Lunak Pendekatan Praktisi (Buku Satu). Yogyakarta : ANDI.

[15] Putra, Nusa. 2015. Research \& Depelopment (Penelitian dan Pengembangan : Suatu Pengantar. Jakarta : PT. RajaGrafindo Persada.

[16] Simarmata, Janner. 2009. Rekayasa Web. Yogyakarta : ANDI.

[17] Sudira, Putu. 2016. TVET Abad XXI (Filosofi, Teori, Konsep dan Strategi Pembelajaran Vocasional). Yogyakarta : Uny Press.

[18] Salahudin, M., \& Rosa, A. 2011. Modul Pembelajaran Rekayasa Perangkat Lunak Terstruktur dan Berorientasi Objek. Bandung: Penerbit Modula.

[19] Sugiyono, 2005. Memahami Penelitian Kualitatif. Bandung : Alfabeta

[20] Sugiyono. 2014. Statistika untuk Penelitian. Bandung: Alfabeta.

[21] Sugiyono. 2014. Metode Penelitian Kuantitatif, Kualitatif, dan Kombinasi (Mixed Methods). Bandung : Alfabeta

[22] Sugiyono, 2004. Metode Penelitian Kualitatif dan $R$ \& D. Jakarta : Alfabeta.

[23] Suprianto, Aji. 2005. Pengantar Teknologi Informasi. Jakarta : Salemba Infotek.

[24] Sobari, Achmad. 2011. Pengembangan Sistem Informasi Berbasis Web (Studi Kasus SLTP Islam Al-Syukro Cupitat). Jakarta : Universitas Islam Negeri Syarif Hidayatullah.

[25] Syachrir, A. 2013. Pengembangan Sistem Informasi Perpustakaan Berbasis Client Server di SMK
Negeri 1 Pallangga, Makassar : PTK UNM.

[26] Stair, R., G. Reynolds. Principles of Information System. 10nd Edition. Course Technology Cengage Learning Bonston. USA.

[27] Tegeh, Made. 2014. Model Penelitian Pengembangan. Yogyakarta : Graha Ilmu.

[28] Teguh, W. 2004. Sistem Informasi (Konsep Dasar, Analisis Desain dan Implementasi). Yogyakarta : GRAHA ILMU.

[29] Tata, Sutabri. 2003. Analisis Sistem Informasi. Yogyakarta : ANDI. 